\title{
Disposal of Fluidized Bed Combustion Ash in an Underground Mine to Control Acid Mine Drainage and Subsidence
}

\section{Quarterly Report}

March 1 - May 31, 1996

Work Performed Under Contract No.: DE-FC21-94MC29244

RECEIVED

For

U.S. Department of Energy

Office of Fossil Energy

Morgantown Energy Technology Center

APR 021997

P.O. Box 880

Morgantown, West Virginia 26507-0880

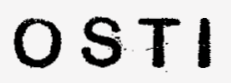

By

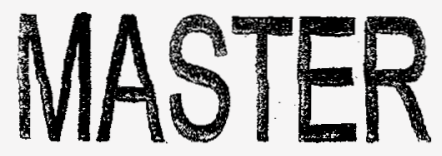

National Research Center for Coal and Energy

West Virginia University

P. O. Box 6064

Morgantown, West Virginia 26506-6064 


\section{DISCLAIMER}

Portions of this document may be illegible in electronic image products. Images are produced from the best available original document. 


\section{Disclaimer}

This report was prepared as an account of work sponsored by an agency of the United States Government. Neither the United States Government nor any agency thereof, nor any of their employees, makes any warranty, express or implied, or assumes any legal liability or responsibility for the accuracy, completeness, or usefulness of any information, apparatus, product, or process disclosed, or represents that its use would not infringe privately owned rights. Reference herein to any specific commercial product, process, or service by trade name, trademark, manufacturer, or otherwise does not necessarily constitute or imply its endorsement, recommendation, or favoring by the United States Government or any agency thereof. The views and opinions of authors expressed herein do not necessarily state or reflect those of the United States Government or any agency thereof. 
Progress Report

for the Period of

\begin{abstract}
March 1, 1996 to May 31, 1996
Project - ETD05 "Disposal of Fluidized Bed Combustion Ash in an Underground Mine to Control Acid Mine Drainage and Subsidence"

DE-FC21-94MC29244
\end{abstract}

During Phase I (first 18 months) the project is segregated into four areas of reporting: A) Grout Formulation, B) Grout Characterization, C) Water Quality Monitoring, D) Subsidence Control \& Contaminant Transport. The first component involves formulating a grout mixture with appropriate flowability to be used in filling complex mine voids. The Grout Characterization component will determine the flow characteristics of the formulated grout. The Water Quality component involves background monitoring of water quality and precipitation at the Phase III (Longridge) mine site. The last component involves evaluating the strength requirements and the migration of contaminants through the candidate grouts.

This report separately discusses progress on all components of the program in order of project subtask. The subtasks are arranged according to the network diagram on the following page. 


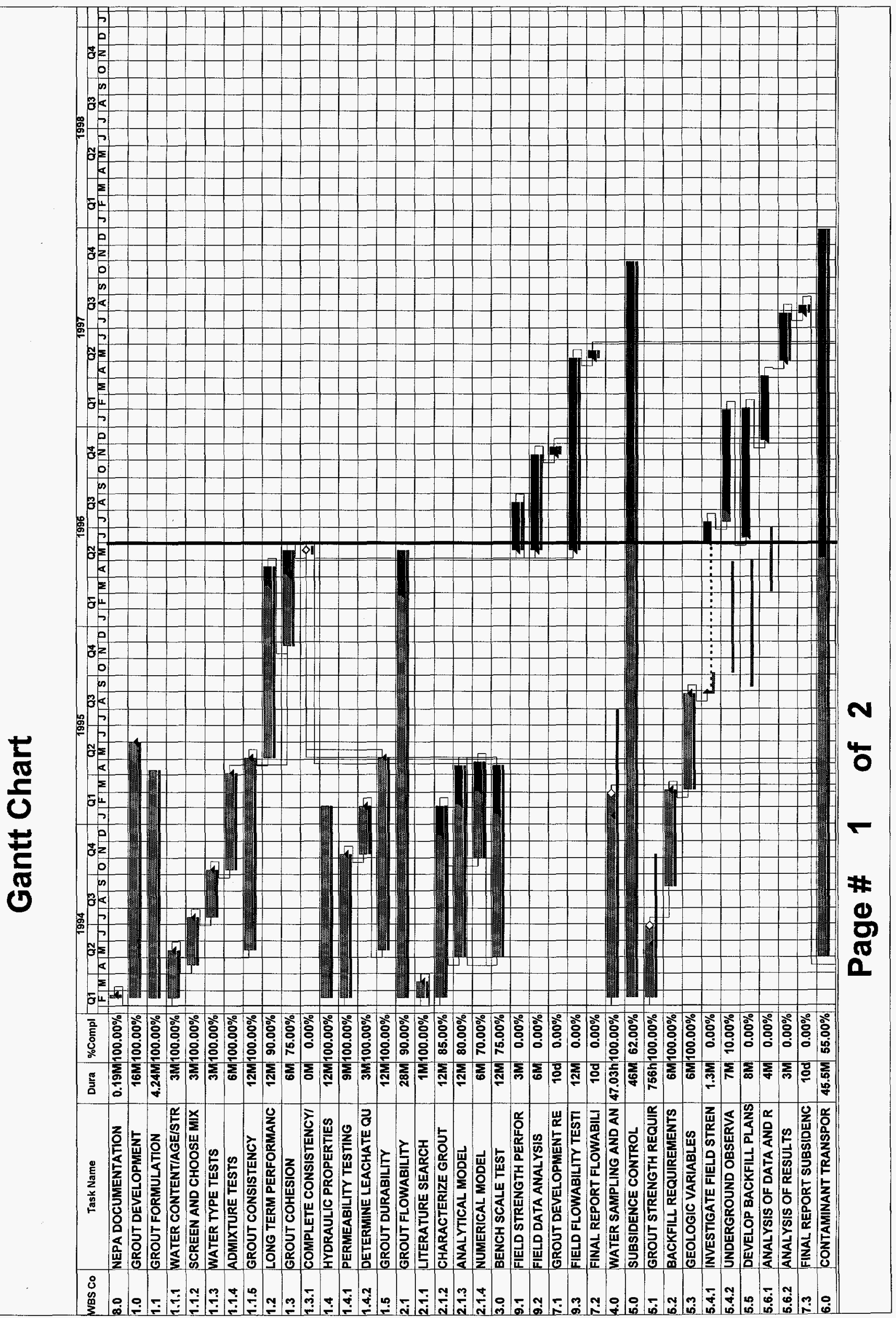




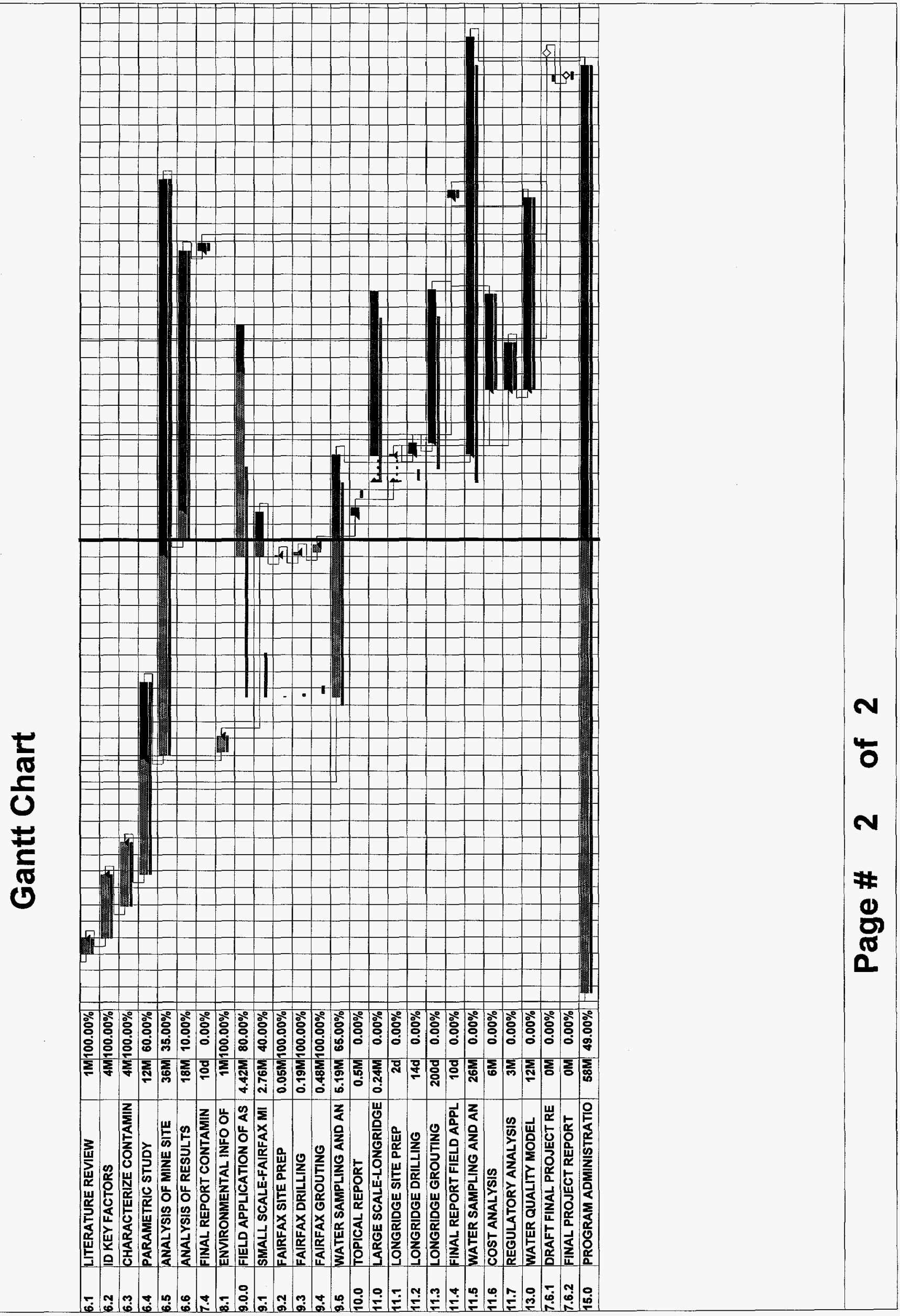




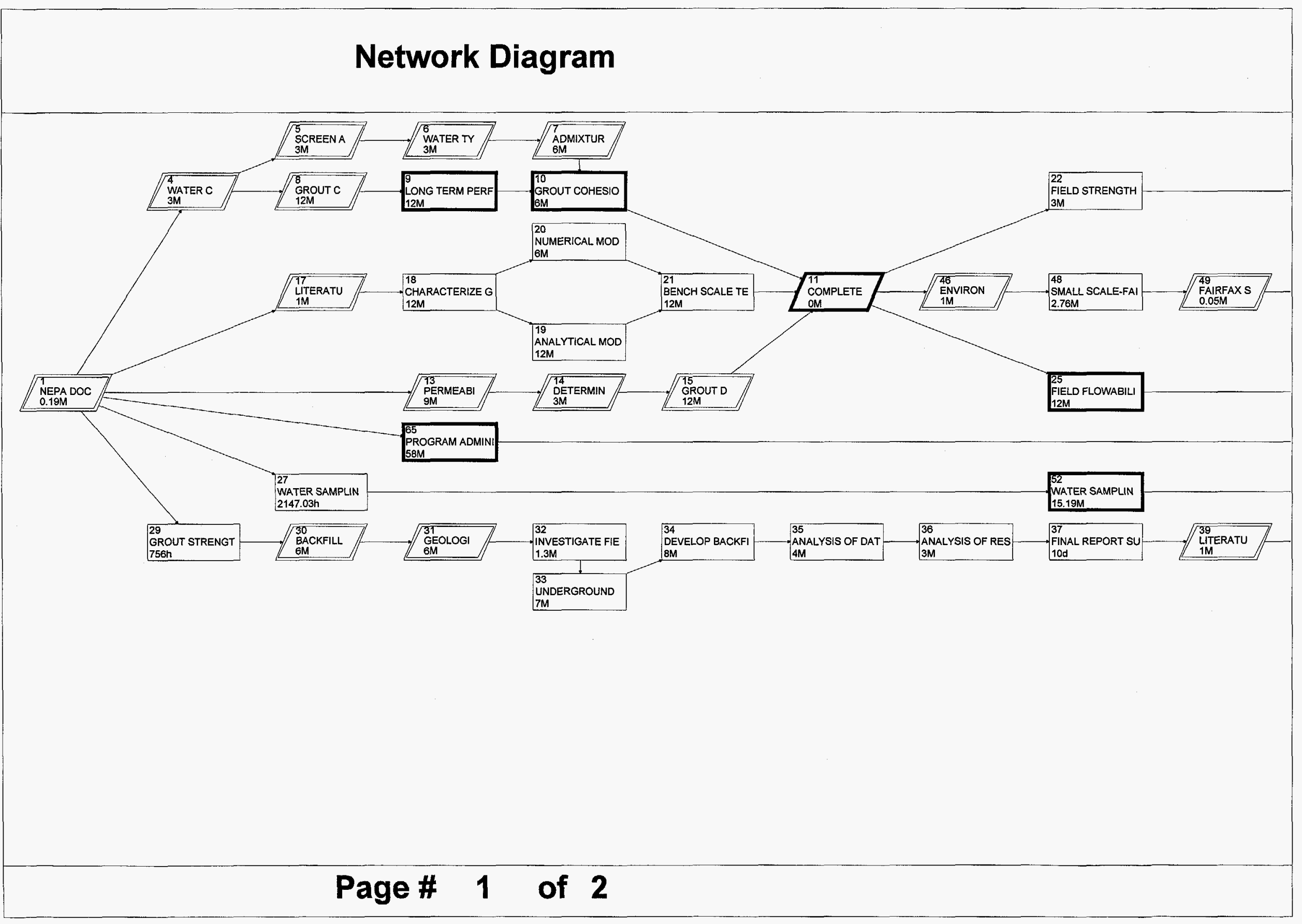




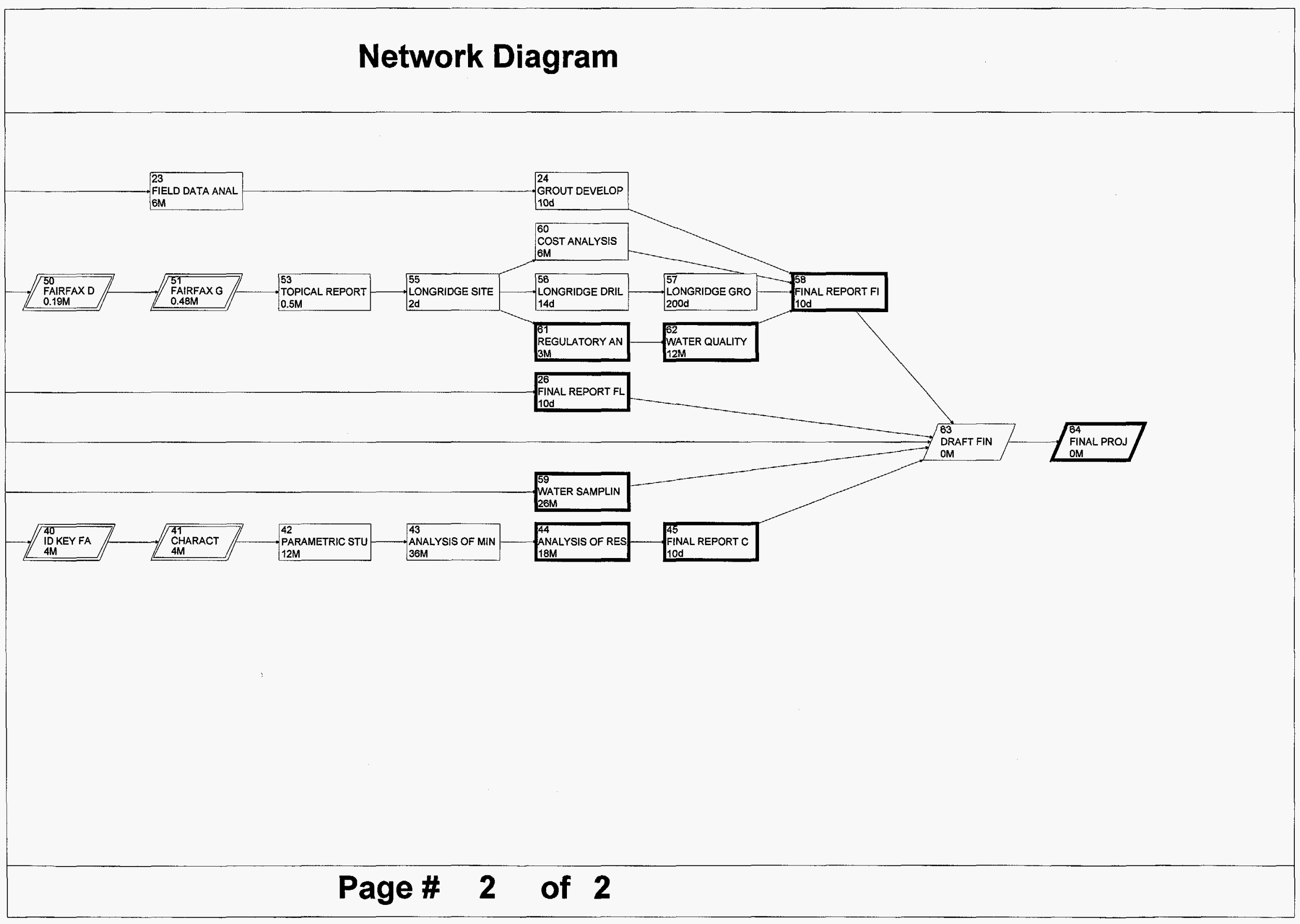




\section{A. Grout Development}

\subsection{Task Description:}

\section{Grout Development}

The purpose of this task is to develop a grout formulation that will be capable of filling complex mine voids while displaying strength great enough to prevent subsidence. This task involves the physical mixing and testing of grouts while keeping in close communication with Dr. Siriwardane's and Dr. Gray's research teams. Dr. Siriwardane's team will evaluate the strength requirements needed for subsidence control while Dr. Gray's team will be responsible for grout rheology.

\subsection{Summary of Accomplishments}

2.1. Monitoring of long-term strength development of various grout mixtures continued; updated plots of strength versus time are attached.

2.2 Monitoring of the affects on compressive strength of changes in ash composition as reflected by time of acquiring ash samples at the plant site was continued.

2.3 Various commercially available admixtures were assessed to determine if such products were useful in enhancing grout strength and/or flow.

2.4 Plans were made for a full-scale field installation of approximately 1000 cubic yards of grout.

\subsection{Grout Field Placement was successfully demonstrated.}

\subsection{To-Date Accomplishments}

As noted above.

\subsection{Technical Progress Report}

Results of laboratory testing of grout mixtures appear in Figures 1-6. Long-term strength test results are shown in Figure 1. Results indicate that strength continues to increase at low rates over a one year period; in addition, strengths vary considerably at any given age with batch number (variation in ash composition) and with lot number (indication of date when ash samples were acquired at the plant). This last variation in ash quality is due to changes in fuel quality at the power plant. As higher sulfur coal is brought into the combuster more limestone is needed to be burned with it to capture the sulfates produced 
during combustion. The residual limestone is of course now part of the ash and causes increases in strength when a grout is produced.

In Figure 2, long-term test results appear for samples made with tap water and similar samples which were submerged in acidic mine water until they were tested. Minor differences occurred between the strengths of the two types of specimens. It appears that grouts may be durable when placed in acidic mine water conditions.

Long-term test results for samples containing bentonite are displayed in Figure 3. Such specimens also continue to gain strength over time. In Figure 4, strength versus time for specimens from the Waynesburg mixing process feasibility demonstration is plotted. Strength continues to increase slowly up to six months. Figure 5 displays strength versus time curves for similar composition specimens made with two different lots of ash. The results again demonstrate that significant variability can be expected in grout strength as a function of conditions in the combuster at the power plant.

Results of strength tests of specimens fabricated with three commercially available admixtures and a conventional, no admixture, mixture are shown. While some admixtures can enhance strength, it appears at this time that mixtures containing only ash and bentonite are adequate for purposes of this project. Such admixtures appear strong enough to sufficiently ameliorate subsidence of relatively shallow cavities while being appropriately flowable in the fresh state. Additional expenses associated with commercially available admixtures appear to be unwarranted at this time.

\subsection{Plans for Next Quarter}

5.1 Continue Monitoring of Long-Term grout strength development.

5.2 Continue laboratory permeability testing of selected grout.

5.3 Sample and test cores taken from field placement of ash at the Fairfax Mine in Preston County. 


\section{B. Grout Rheology}

\subsection{Task Description}

1.1 Literature Search: This task will involve both manual and computer searches of the literature on several topics. This task will insure that the latest advances in grout technology are incorporated into this project and that no effort is wasted in the duplication of results.

1.2 Grout Characterization: In this task, appropriate viscometric tests will be conducted to determine the relationship between stress and rate of strain, as a function of time and composition of the grout mixture.

1.3 Analytical Modeling: This task is the development of an analytical model to describe the rheology of the grout. This task will provide a constitutive relation that describes the behavior of the grout in agreement with the laboratory results.

1.4 Numerical Modeling: This task includes the adaptation of commercially available fluid modeling software to incorporate the rheological model developed in task 1.3. This task will enable the placement of grout to be modeled numerically.

\subsection{Summary of Accomplishments \& Significant Events}

Literature Search: $100 \%$ complete Grout Characterization: $85 \%$ complete Analytical Model: $80 \%$ complete Numerical Model: $70 \%$ complete

\subsection{To Date Accomplishments}

The literature search may be considered complete, but new information about the project is continually being revealed. No other tasks are complete to date.

\subsection{Technical Progress Report}

\subsection{Grout Rheology}

The mixer viscometer technique for grout characterization using the combination of the Brookfield LVDV-III rotational viscometer with T-bar spindles and the vane method is being perfected. The slope and intercept from the plot of torques versus spindle speeds from the viscometer and values of the yield stress from 
the vane method are being analyzed using the Mettzner and Tattersall method for finding the constitutive law of the grout.

Further tests with a recipe of $47-52 \%$ water fraction and $7 \%$ bentonite have been performed, and the mixture seems to be adequately flowable. The values of flow parameters like the viscosity and the yield stress are yet to be quantitatively established. The bleed tests performed have established that the said recipe is adequately stable. Later, a combination of bentonite and the superplasticizer as the stabilizer will be worked on, if time and funding permit.

A paper describing the mixer viscometer technique was presented at the American Society of Civil Engineers, Engineering Mechanics Conference on May 20, 1996.

\subsection{Site Injection}

The test injection of the grout was conducted at the Fairfax mining site in the Preston county on May 20,1996. About $1000 \mathrm{yd}^{3}$ of grout was injected over a period of 5 days. A recipe of $34 \%$ water fraction (this is the amount added at the site and does not include the moisture present in the ash that reached the site ) and $5 \%$ bentonite was adopted for the injection purpose. A $40 \mathrm{yd}^{3} / \mathrm{hr}$ capacity concrete pump was used to pump the grout through a 4 " diameter injection hole.

The results of the injection were very encouraging and the grout exhibited the required standards of flowability and stability. A spread of $600 \mathrm{ft}$ of running length of the mine corridor, $18 \mathrm{ft}$ wide was achieved from a single injection hole. The height to which the grout build up was about $2 \mathrm{ft}$ at the injection point to about 6 " midway through the length. The onsite spread tests showed an spread of about 14". The test also shows that the dip on the floor had a significant influence on the direction of flow.

\subsection{Numerical Model}

For the numerical simulations of the flow of grout in the mine cavities to be extended to 3D domains, the convergence of the scheme and the computer time for simulations are critical. With the realistic pumping speeds and the present time steps size for convergence of the numerical model, the computer time for $3 \mathrm{D}$ simulations is expected to be impracticably high.

A grid size and time step has been worked out which can be used to simulate prolonged injection time. A domain that amply represents the mine is being worked upon, BFC grid is also being looked into as a possible way to achieve this.

\subsection{Observations of Grout Flow from Underground while Injecting}


The following observations were made by Dr. Paul F. Ziemkiewicz of the National Mine Land Reclamation Center at West Virginia University. Dr. Ziemkiewicz was underground while the first four truckloads of grout were being injected.

Injection began at 9:35 am,21 may 1996. Johnnie Nichols, mine superintendent and Paul Ziemkiewicz were in the mine, $75 \mathrm{ft}$. From the injection borehole when injection began. FBC ash slurry was injected in batch mode from two alternating cement trucks on the surface. Each pour comprised about 9-10 cu yds of slurry. Each pour lasted about 20 minutes and the interval between pours was 5-10 minutes.

Pour \#1 flowed 75 feet from the borehole. At the downstream end of the ash lobe its depth was about 1 inch. At the borehole the depth was about 2 inches. The ash front continued to advance until injection stopped. The slurry was very fluid, finding and progressively filling low spots. It formed a leveled channel between 1 to 2 foot wide with the narrower widths associated with higher flow rates over constrictions and overfalls. In incompletely filled headings, slurry flowed down the center line of a channel which was semicircular in cross section, $\sim 4$ foot wide and 3 inches high at the center line. These channels eventually became occluded, at which side channels would break out and initiate a new lobe.

Pour \# 2 advanced a further 75 feet. Upon the subsequent pours, the slurry front remobilized with a roughly 1 minute lag time, initiated by a roughly $1 / 2$ inch wave which propagated in line with the axis of advance. The wave was parabolic with its apex at the downstream end. The second pour did not ride over the first pour, rather it displaced it from the upstream end pushing the entire mass forward. Shale rocks (4-6 inches long, 2 inches square) were observed carried along with the slurry. Slurry velocity was 12 inches/sec at overfalls and more typically 6 inches/sec on the level floor.

Pour \#3 advanced only another foot or so, but it spread out to fill two headings from pillar to pillar (18 ft heading width). At the end of pour \#3 the thickness at the downstream end was 2 inches. A zone of bleed water about $1 / 2$ inches was observed at the downstream end of the slurry. Between pours, when the slurry advance stopped a thin (1-2 $\mathrm{mm}$ ) layer of bleed water could be seen moving slowly along the top of the slurry. At the end of Pour \#3 slurry depths were 2 inches at the downstream end, 6 inches in a low spot at the first spad (center of intersection) and 4 inches at the borehole.

There appeared to be some particle size segregation with higher sand contents at the borehole and in the main channels with more fines at the downstream end and in the side channels and bays. 
Slurry flowed down the 1-2\% slope of the mine floor. It would dam behind roof falls and floor irregularities then flow over or around.

Pouring continued until 5:30 pm on the first day. About 125 cubic yards of slurry were injected on the first day.

The slurry was warm to the touch but not uncomfortable (like bathwater). It generated a good deal of vapor. Also, since AMD treatment water was used to make up the slurry, and the AMD was treated with $\mathrm{NH}_{3}$, contact with the lime caused deprotonation of the ammonium ion and release of more than perceptible amounts of $\mathrm{NH}_{3}$.

\section{Day Two}

Results of the previous day's injection: About $5,400 \mathrm{sq}$. Ft. of mine floor were covered by the end of the first day to an average depth of about 8 inches. While floor elevation varied in the order of 1-2 ft from roof fall, the slurry had the effect of leveling to an almost planar surface. From an almost watery consistency the first day the slurry had set up slightly to a Jell-O consistency. At the end of the day one the injection crew ran about 800 gallons of water down the line to clean out the pump. This flushed out the slurry channels leaving them free for the next day's slurry.

Witnessing the injection underground on day two were: Johnny Nichols, Fairfax Fuels; Jeff Kelley, and two engineers from Anker Energy, Inc; Dwayne Maust and Dave Bayles from Patriot Mining, Inc.; Mike Main and Paul Ziemkiewicz from WVU.

Injection began at 7:30 am and while deforming the day one slurry in the immediate vicinity of the injection borehole, the new slurry flowed on top of the old slurry. It did not remoblize the old slurry to any significant extent.

Since the FBC ash had been allowed to sit out overnight in a thunderstorm, it had developed a crust. This was broken up into 2-3 in diameter chunks which were transmitted with the slurry. These could be seen floating by in the slurry channel.

With well developed channels, flow proceeded in surges particularly at constrictions and overfalls. Velocity would decelerate over a period of minutes, stop for a second or so, then release in a surge. The flow would then spread out evenly behind a small ( 1 in) wave below the overfall.

Injection proceeded to 24 may 1996 until 1,000 cu yds were placed in the mine. The next in-mine visit occurred one week after injection on 31 May 1996. 
One Week After Injection

On 31 May 1996 a party consisting of: Johnny Nichols, Fairfax Fuels; Jer-Yu Chang, Scott Renninger, U.S. Department of Energy; Milton Wu, Bruce Leavitt, CONSOL, Inc; Jeff Young, WW Public Radio; Ed Lyons, Maryland DER; Jeff Skousen, Courtney Black, Therapatti Reddy and Paul Ziemkiewicz, WVU inspected the mine.

By this time the slurry had solidified to the extent that samples had to be chopped out with an entrenching tool. In spots of $>6$ inches of slurry tit was still moist 3 inches from the top. The slurry had developed cracks which penetrated about 4 inches. These tended to run normal to the direction of ash flow. The ash had flowed about $550 \mathrm{ft}$ from the injection borehole and surrounded four pillars. Headings were filled pillar to pillar and some rooms were filled with $2 \mathrm{ft}$ of slurry (the roof was $4 \mathrm{ft} \mathrm{high).} \mathrm{At} \mathrm{the} \mathrm{injection} \mathrm{borehole} \mathrm{the} \mathrm{slurry} \mathrm{had} \mathrm{coned} \mathrm{but}$ was still about 10 inches from the roof. 


\section{Water Quality Monitoring}

\subsection{Task Description}

\section{Baseline Water Quality Monitoring}

The purpose of this task is to monitor the baseline water quality of the acid mine drainage (AMD) from the Longridge and Fairfax Mines prior to and during grouting. A flow monitoring and sampling station has been set up at the Longridge mine and a precipitation gauge has been established between the two mines.

\subsection{Summary of Period's Accomplishments \& Significant Events}

Initiated sampling of the borehole that is located in the aquifer below the Fairfax mine. The purpose of this monitoring progrtam is to determine if any metals are leaching from the grout that was placed in the Fairfax Mine. The borehole will be sampled for the remainder of the project.

\subsection{Accomplishments to Date}

Accomplishments to date include choice of parameters to sample, design of the sampling station, procurement of equipment, site preparation, installation and shake down of equipment, initiation of sampling and data analysis.

\subsection{Technical Progress Report}

A report of the flow, precipitation monitoring, water quality and miscellaneous issues related to monitoring activities will be presented in the Phase II Topical Report due at the end of July 1996.

\subsection{Plans for next Quarter}

5.1 Continue monitoring the Longridge mine for water quality and flow.

5.2 Continue to monitor Fairfax borehole for possible contamination from grout. 


\section{Subsidence Control and Contaminant Transport}

\subsection{Task Description}

\section{Task 5.0 Subsidence Control}

Determine grout strength requirements needed to ensure subsidence control. Also development of borehole drilling pattern for the Phase II and Phase III mine sites.

\section{Task 6.0 Contaminant Transport}

Determine how contaminants will migrate from the grout (if any) and determine how the water that was filling the void will interact with the impermeable plug filling the void after injection.

\subsection{Summary of Quarters Accomplishments and Significant Events}

2.1 The grout strength requirements were established to account for possible stress concentrations around mine cavities.

2.2 The Longridge Mine was idealized to perform contaminant transport studies and some example flow problems were solved.

\subsection{To Date Accomplishments}

3.1 Started work on the final report for the grout strength requirements part of the project.

3.2 Continued work on finding the factor of safety to be used as a theoretical strength requirements of the grout to account for stress concentrations around mine cavities.

3.3 The Longridge Mine was idealized for the task on modeling the contaminant transport.

3.4 A finite element difference grid for the idealized Longridge mine was constructed and some example groundwater flow problems were solved using the existing computer software.

\subsection{Technical Progress Report}

4.1 Grout Strength Requirement and Subsidence Control 
the preparation of the final report for the grout strength requirement and subsidence control is underway. An independent finite Element analysis was performed to obtain information on the potential safety factor to be used on the theoretical strength requirements of the grout to account for stress concentrations around mine cavities. Figure 7 shows the variation of stress concentrations with elastic modulus and Poisson's ratio of the grout for two different overburden materials. From this Figure, it is seen that the overburden stiffness has a marked effect on the stress concentration factors. For areas overlain by a stiff overburden (elastic modulus of the order of $5.6 \times 10^{6} \mathrm{psi}$ ) the stress concentration factor decreases with an increase in the elastic modulus of the grout and reaches a value close to 1.0 for values of elastic modulus equal to that of the overburden $\left(5.6 \times 10^{6} \mathrm{psi}\right.$ in this case $)$.

In the case of a weak overburden the stress concentration factor remains almost constant with a value close to 1.0 for different values of elastic modulus of the grout after reaching a peak value of 3.16 for the cavity around the grout. It can be seen from this Figure (Figure 7) that for a grout that has a typical elastic modulus equal to $0.5 \times 10^{6} \mathrm{psi}$, the value of the stress concentration factor to be used for obtaining the stress requirement may vary in the range of 2.5 to 2.75 . It can also be seen that Poisson's ratio plays little role in affecting the values of the stress concentration factors.

For a real time situation, the overburden is likely to have a stiffness value in between the two scenarios considered in the previous section. Thus, the stress concentration factor to be used as a safety factor to offset the effect of stress concentrations around mine cavities may be close to 2.5 for practical purposes. Tables 1 and 2 include the strength requirements for the grout to be used as backfill material a the Fairfax and Longridge mines to account for potential stress concentration around mine cavities; these tables are based on a safety factor of 2.5. Additional considerations should be given to account for other uncertainties such as grout segregation during placement, mine water content, and other factors that influence the grout strength.

\subsection{Contaminant Transport}

An idealized map of the Longridge mine was made in the following manner:

- A base map of the Longridge mine was obtained, the pillars were numbered and the pillar and hallway dimensions were measured.

- The pillar and hallway dimensions were approximated in the map to obtain a more uniform configuration of dimensions for the modeling phase.

- The actual catchment area (identified earlier) was approximated by a rectangular are. Figure 8 shows the idealized pillar and hallway dimensions.

An example fluid flow problem was defined and solved for the idealized Longridge mine. This was done to check the effect of the geometric 
discretization of the Longridge mine on numerical results obtained from computer models. As shown in Figure 9, the discretizated problems has three layers, 54 rows and 13 columns. The middle layer was assumed as the coal seam as shown in Figure 10.

The middle (mine) layer in this problems was treated as a non-homogeneous layer with different properties assumed for the hallways and pillars.

Transmissivity and leakance are the two geohydrologic properties that represent permeability of the material in the horizontal and vertical directions, respectively. Low values of transmissivity and leakance maybe assumed for the hallways to simulate a condition where the hallways are grouted. A high value of transmissivity and leakance maybe assumed for the hallways to simulate a condition where there is no grout.

In this problem transmissivity and leakance of the hallways are assumed to be 1000 times less than that of the pillars to simulate hardened grout in the hallways. Three injection wells located in the mine layer and one drain is located in the bottom layer. The boundary conditions and properties used in the present problem are shown in Table $3 a$ and Table $3 b$.

The results obtained from the computer analysis of the flow problem show that there is no numerical error caused by the geometric discretization of the Longridge Mine. The low permeability zones where the grouted hallways are located seem to dictate the fluid flow patterns in the mine layer. Using the results from the flow analysis, a contaminant transport analysis will be done next.

\subsection{Plans for Next Quarter}

To continue the analysis of fluid flow and contaminant transport problems at the Longridge Mine.

\section{References}

1. Todd, David Keith, "Groundwater Hydrology," John Wiley and Sons, Inc., 1976.

2. Freeze, R Allan and Cherry, John A, "Groundwater," Prentice Hall, Inc., 1976. 


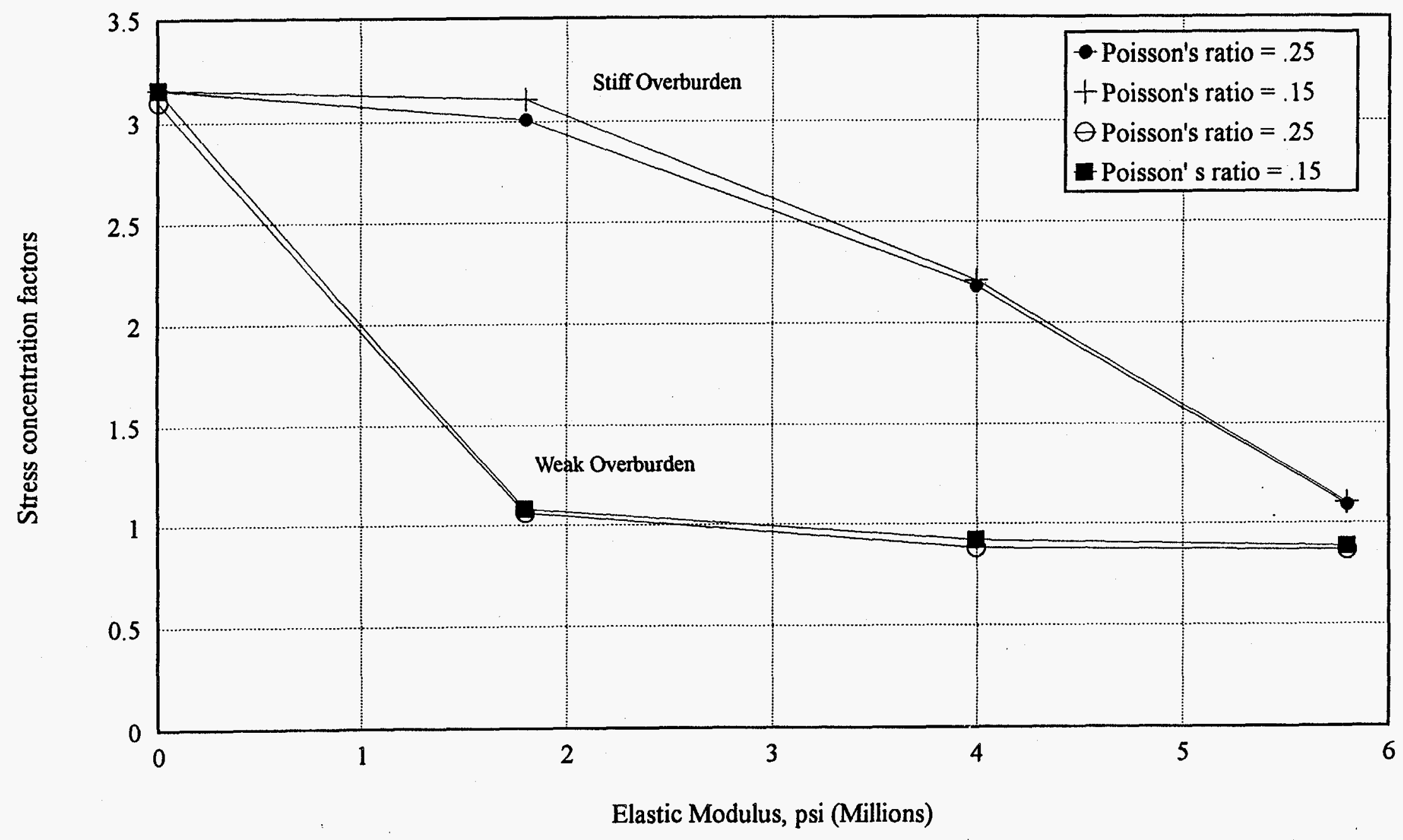

Figure 7: Stress Concentration Factors around Mine Cavities 
Table 1: Strength Requirements for the Grout at the Fairfax Mine

\begin{tabular}{|c|c|c|c|c|c|}
\hline Core Holes & $\begin{array}{c}\text { Computed Stress at the } \\
\text { level of coal seam (psf) }\end{array}$ & $\begin{array}{c}\text { Stress (psi) } \\
\text { Factor of Safety } \\
\text { to account for } \\
\text { Stress } \\
\text { Concentrations* }\end{array}$ & $\begin{array}{c}\text { Strength } \\
\text { Requirement for } \\
\text { the Grout (psi) }\end{array}$ \\
\hline \hline SQ-41 & 34,495 & 239.0 & 2.5 & 600 \\
\hline SQ-42 & 35,035 & 243.0 & 2.5 & 608 \\
\hline SQ-43 & 32,815 & 227.0 & 2.5 & 570 \\
\hline
\end{tabular}

Table 2: Strength Requirements for the Grout at the Longridge Mine

\begin{tabular}{|c|c|c|c|c|}
\hline Core Holes & $\begin{array}{l}\text { Computed Stress at the } \\
\text { level of coal seam (psf) }\end{array}$ & Stress (psi) & $\begin{array}{l}\text { Factor of Safety } \\
\text { to account for } \\
\text { Stress } \\
\text { Concentrations* }\end{array}$ & $\begin{array}{l}\text {-y Strength } \\
\text { Requirement.for } \\
\text { the Grout (psi) } \\
\text { the }\end{array}$ \\
\hline LR-29 & $8,982.5$ & 62.0 & 2.5 & 155 \\
\hline LR-33 & $10,488.5$ & 72.0 & 2.5 & 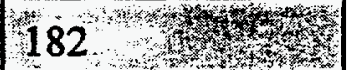 \\
\hline LR-34 & $5,456.25$ & 38.0 & 2.5 & $96, y=3 x$ \\
\hline LR-42 & $14,905.5$ & 103.0 & 2.5 & 260 \\
\hline
\end{tabular}

* Based on finite element analysis performed to study the effect of stress concentrations around mine cavities. 


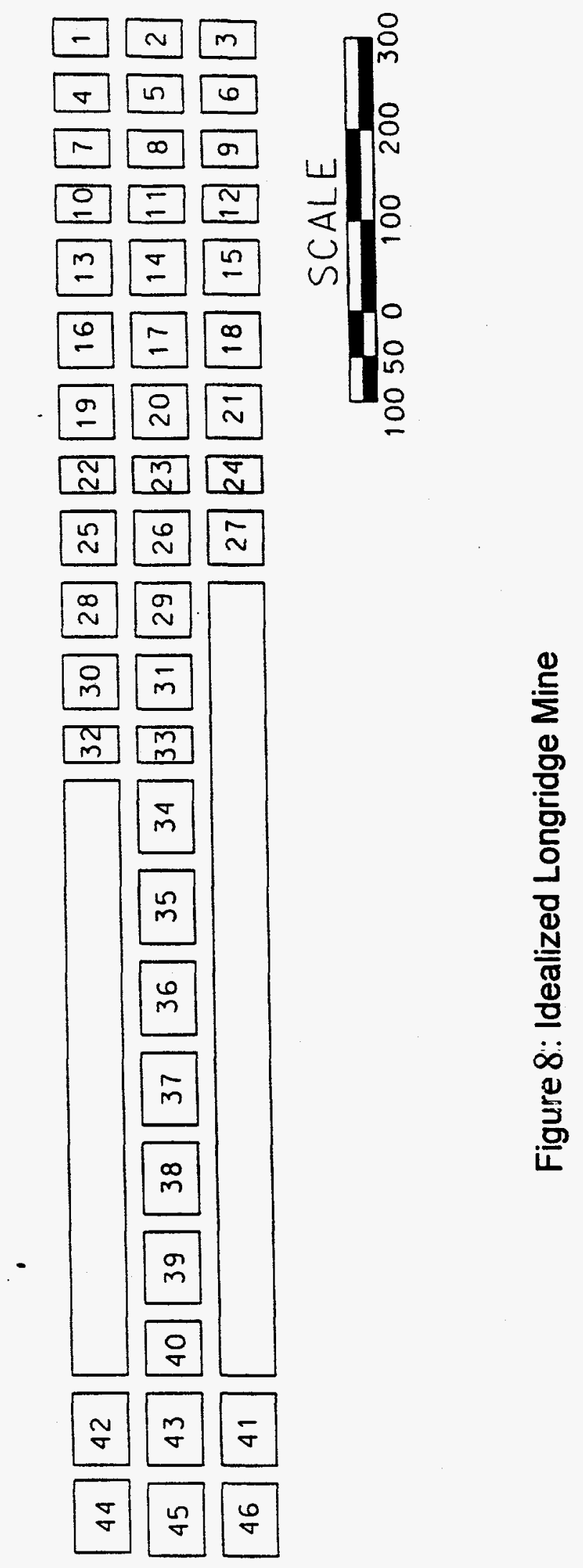




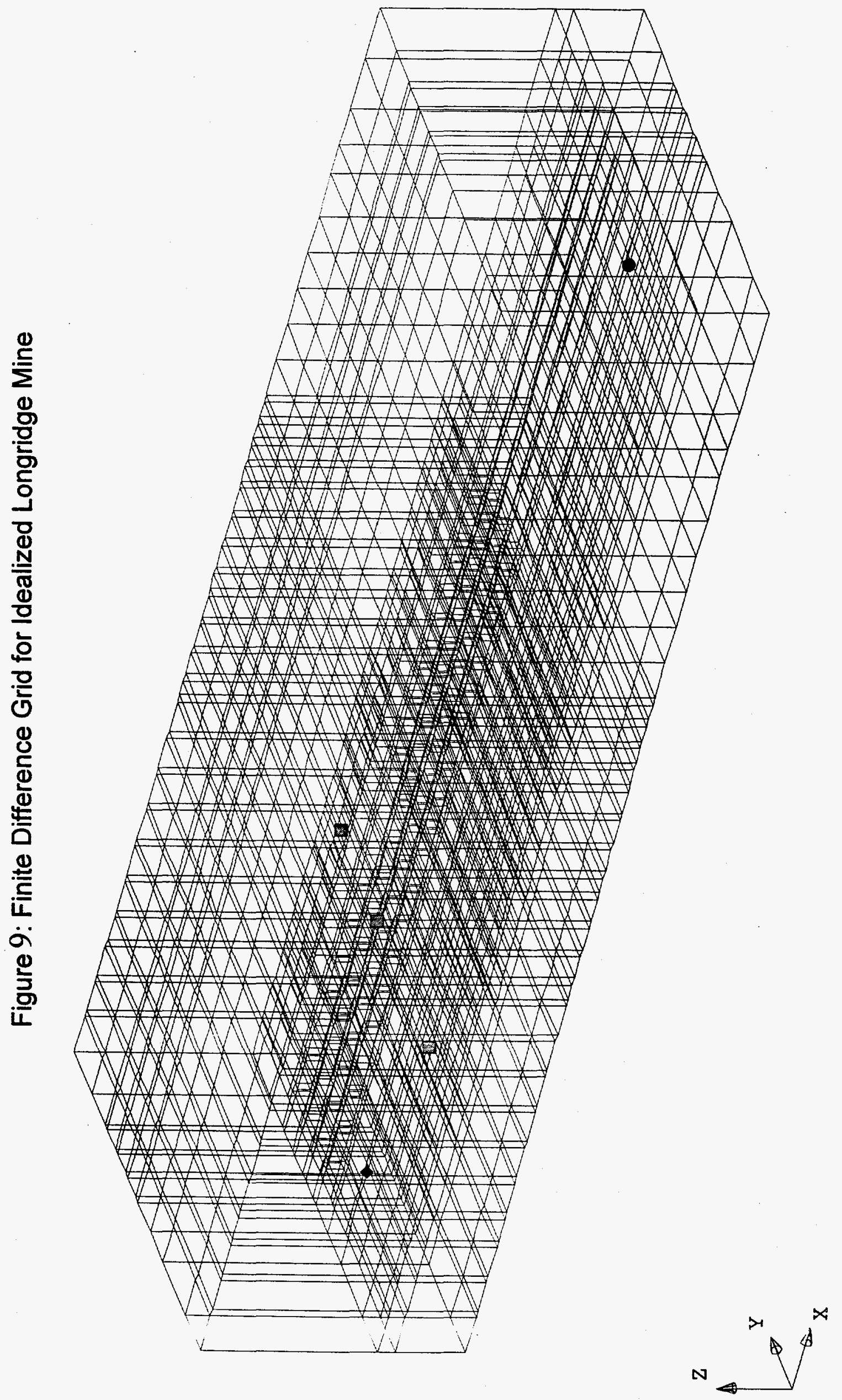




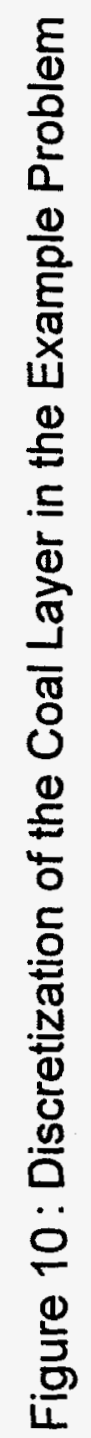

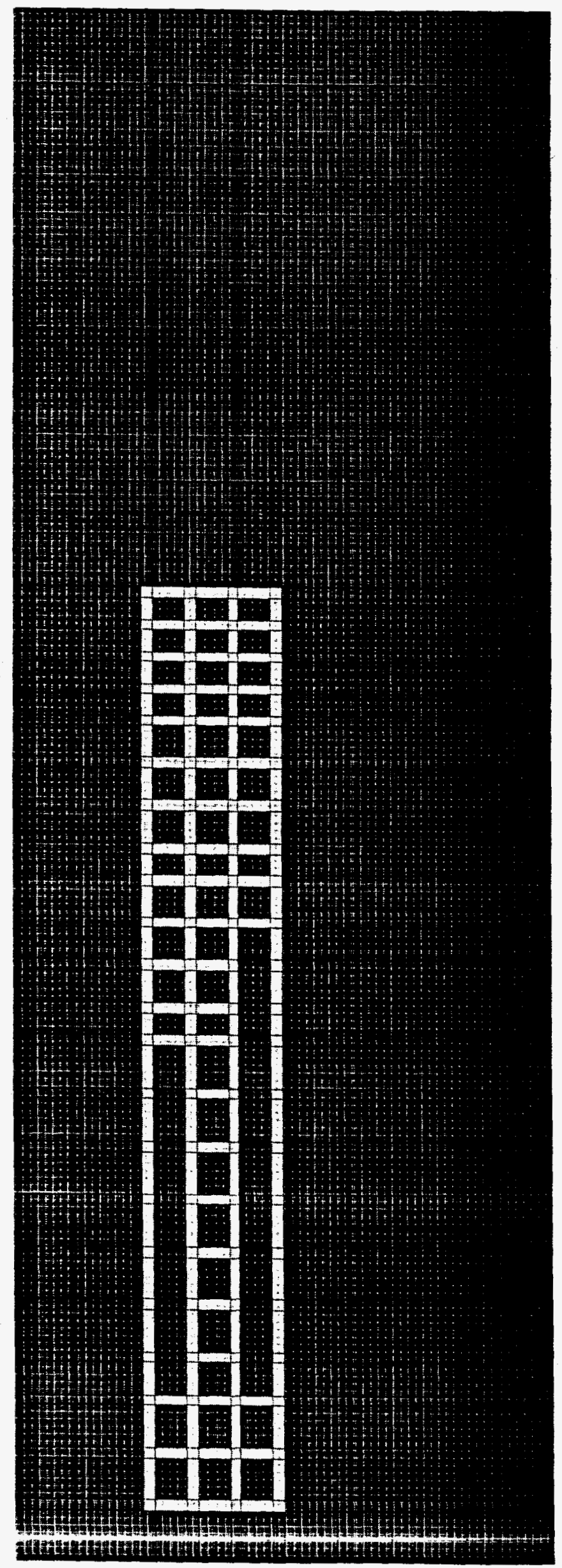


Table3-a: Boundary Conditions used in example longx8-2

\begin{tabular}{|l|c|l|}
\hline Type & Location & Value \\
\hline $\begin{array}{l}\text { Constant } \\
\text { Heads (feet) }\end{array}$ & $(1,6,3)$ & 125 \\
\hline Wells ( $\mathrm{ft}^{3} /$ day) & $(14,8,2),(14,2,2),(14,13,2)$ & 15 \\
\hline $\begin{array}{l}\text { Drains } \\
\text { (conductivity) }\end{array}$ & $(52,7,3)$ & 45 \\
\hline
\end{tabular}

Table 3-b: Properties used in example longx8-2

\begin{tabular}{|l|l|l|l|l|}
\hline Property & Layer1 & \multicolumn{2}{l|}{ Layer2 } & Layer3 \\
\hline Type & unconfined & \multicolumn{2}{l|}{ conf./unconfined } & confined \\
\hline$-\cdots$ & $-\cdots$ & hallway & other & - \\
\hline $\begin{array}{l}\text { Hydraulic Conductivity } \\
\text { (ft/day) }\end{array}$ & 0.2 & NR* & NR & NR \\
\hline Transmissivity (ft'/day & $\mathrm{NR}$ & 0.002 & 2 & 6.0 \\
\hline Leakance (/day) & 0.004 & 0.00008 & 0.08 & $\mathrm{NR}$ \\
\hline Layer Bottom (ft) & 50 & $\mathrm{NR}$ & $\mathrm{NR}$ & $\mathrm{NR}$ \\
\hline Layer Top (ft) & $\mathrm{NR}$ & 50 & 50 & $\mathrm{NR}$ \\
\hline Recharge $(\mathrm{ft} /$ day) & 0.0098 & $\mathrm{NR}$ & $\mathrm{NR}$ & $\mathrm{NR}$ \\
\hline
\end{tabular}

*Not Required 